\title{
The Governance and Disclosure of the Firm as an Enterprise Entity
}

\author{
Yuri Biondi $i^{*}$
}

\section{INTRODUCTION}

During recent decades, the rapid pace of financial markets involving new modes of management, governance, and regulation has framed business firms. This corporate drift toward financialization is summarized under the "shareholder value" label. What do financial markets do? Unequivocally, they organize trading on shares that are securities: tradable financial entitlements established by law, which formalize expectations, and claims of financial rents paid by the issuing company. ${ }^{1}$ Actually, how continued quotation on share exchanges came to be the barometer of economic or social welfare is a different matter. The latter adoption has required quite a great leap from "the euthanasia of the rentier, of the functionless investor" involving changes in, and reforms of, monetary and financial architectures at policy-making and regulatory levels; banking and financial institutions; shareholding, monetary, and

\footnotetext{
* I thank Thomas Clarke, Fernando Polo Garrido, William Lazonick, Antoine Reberioux, Lynn Stout, Shyam Sunder, Olivier Weinstein, and Geoffrey Whittington for insightful comments and discussions. I also thank Sarah Albertson for her valuable editorial assistance. This paper was presented at the Fourth International Symposium ("The Future of Financial and Securities Markets") of the Adolf A. Berle, Jr. Center for Corporations, Law and Society, held at the Faculty of Laws, University College London on June 14 and 15, 2012, and at the International Workshop on Accounting for Cooperatives of the Centre for Research in Business Management (Centro de Investigación en Gestión de Empresas), held at the Universitat Politècnica de València (UPV) in Spain on September 29 and 30, 2011. A previous version was included in the working paper series Comparative Research in Law and Political Economy, CLPE Research Paper No. 21 (2009), together with the proceedings of the European Association for Evolutionary Political Economy (EAEPE) International Conference on "Governing the Business Enterprise: Ownership, Institutions, Society," held at the Conservatoire des Arts et Métiers (Cnam) in Paris on May 22 and 23, 2008. Additional information on the latter conference is available at http://yuri.biondi.free.fr/EAEPE.CNAM.2008/index.html.

1. Together with shares, including their issuance and buyback, other financial arrangements deal with the linkage of finance to business activities, including bonds and debts, structured financial instruments, stock options, and pension schemes.

2. John M. Keynes, The General Theory of Employment, InTERest, AND Money 376 (1936) (emphasis added).
} 
investment funds (including pension and insurance); and the management, organization, and accounting of business firms. This general trend has been further shaped by transnational imitation between various socioeconomic environments and regulatory regimes, led by some global institutions. $^{3}$

The shareholder value revolution has involved peculiar beliefs and ideas on (1) what financial markets can actually do, and (2) what they are indirectly concerned with - that is, ongoing firms having internal organization and management. Shareholder value relates to the efficient financial markets rhetoric (point 1). ${ }^{4}$ Behind its academic foundations in the late developments of neoclassical financial economics, ${ }^{5}$ securities market makers utilize this rhetoric to affirm their social role and advertise their financial "products" to clients and citizens. Belief in the magic of the share exchange is fuelled, and firms become the very commodity that trading is constructed upon. Financial markets trade on legal entitlements whose "values" relate - in principle - to financial performance and position of business firms. ${ }^{6}$ In order to be submitted to securities marketstoday considered as the center of economy and society-business firms have been reduced to financial placements (point 2). The peculiar efficient market rhetoric already applied to the working of financial markets is then replicated within the firm. The latter comes to be seen as a portfolio of disparate financial assets and liabilities held on behalf of investors, who trade on shares issued by the firm itself. On this basis, shareholder value has reshaped the corporate activity, fostering new practices of integrated financial management. ${ }^{7}$

3. See generally Vincent Bignon, YuRi BIONDi \& XAVIER RAGOT, AN ECONOMIC ANALYSIS of Fair Value: Accounting as a Vector of Crisis (2009); SPeCial Issue: The SocioEConomics of AcCounting, 5 Socio-Econ. Rev. 585 (Yuri Biondi \& Tomo Suzuki eds., 2007); Richard Deeg \& Gregory Jackson, Towards a More Dynamic Theory of Capitalist Variety, 5 SocIOECON. REv. 149 (2007); Steven L. Schwarcz, Framing Address: A Framework for Analyzing Financial Market Transformation, 36 SeAtTle U. L. REV. 299 (2013); Karel Williams, From Shareholder Value to Present-Day Capitalism, 29 ECON. \& SoC'Y 1 (2000); Yuri Biondi et al., Governing the Business Enterprise: Ownership, Institutions, Society (Comparative Research in Law \& Political Econ., Working Paper No. 13/2009, 2009), available at http://ssrn.com/abstract=1440889.

4. See sources cited supra note 3 and infra note 7.

5. Cf. Yuri Biondi, Disagreement-Based Trading and Speculation: Implications for Financial Regulation and Economic Theory, 1 ACCT. ECON. \& L. 1 (2011) [hereinafter Biondi, DisagreementBased Trading]; Yuri Biondi, Money Without Value, Accounting Without Measure: How Economic Theory Can Better Fit the Economic and Monetary System We Live In [hereinafter Biondi, Money Without Value], in Money and CAlculation: ECONOMic AND Sociological Perspectives 34 (Massimo Amato, Luigi Doria \& Luca Fantacci eds., 2010); Yuri Biondi, Pierpaolo Giannoccolo \& Serge Galam, What Does Financial Market Do? The Formation of Share Market Prices Under Heterogeneous Beliefs and Common Knowledge, 391 PHYsICA A 5532 (2012).

6. Issuance from governments and other entities are neglected here for the sake of simplicity.

7. See generally Margaret M. Blair, Shareholder Value, Corporate Governance, and Corporate Performance: A Post-Enron Reassessment of the Conventional Wisdom, in CORPORATE 
According to Karl Polanyi, classical and neoclassical economic theories are characterized by an alleged extension of "our obsolete market mentality" to every socioeconomic activity. ${ }^{8}$ A combination of market and ownership then reveals the true value of everything through market prices, generating a spontaneous economic and social order among liberated individuals. Polanyi's seminal work, The Great Transformation, identified three "fallacious commodities": land, money, and human work. ${ }^{9}$ While these three human activities are significant for the economy and society, they do not imply either the existence of, or the need for, market coordination.

The same fallacy applies to the firm nowadays. Shareholder value fallaciously reduces the firm to a commodity, taking the form of a tradable security. A firm is factually a significant socioeconomic activity, but its reduction and reification to ownership rights traded on financial markets features the shareholder value rhetoric. While trading factually exists on shares and other legal entitlements issued through the legal structure of the firm, only the shareholder value rhetoric argues that the whole economy of the business firm does - and should - depend on that share market pricing throughout time.

This paper aims to address some theoretical problems with shareholder value that come from its misguided understanding of shareholding and the business firm. Shareholder value relies on complementary views that point to market and ownership to understand the dynamics of both securities markets and the enterprise activity. But what happens when shares, acquired at a definite price in a given circumstance, relate to the enterprise congeries of legal and economic systems involving flows and immobilizations that require an accounting system to explicate them?

Governance and Capital Flows in a Global Economy (Peter Cornelius \& Bruce M. Kogut eds., 2003) (providing legal-economic preconceptions); William Lazonick, The Financialization of the U.S. Corporation: What Has Been Lost and How It Can Be Regained, 36 SEATtLE U. L. ReV. 857 (2013); Williams, supra note 3; see also Michel AGLIETTA \& ANTOINE REBÉRIOUX, Corporate Governance Adrift: A CritiQue of Shareholder Value (2005) (providing insightful macroeconomic analysis); Robert Boyer, Is a Finance-Led Growth Regime a Viable Alternative to Fordism? A Preliminary Analysis, 29 ECON. \& SOC'Y 111 (2000) (providing insightful macroeconomic analyses); Julie Froud et al., Shareholder Value and Financialisation: Consultancy Promises, Management Moves, 29 ECON. \& SOC'Y 80 (2000) (discussing the managerial foundations of shareholder value); William Lazonick \& Mary O'Sullivan, Maximizing Shareholder Value: $A$ New Ideology for Corporate Governance, 29 ECON. \& SOC'Y 13 (2000) (discussing the managerial foundations of shareholder value). In addition, Thomas Clarke edited a comprehensive collection on theoretical foundations of corporate governance, entitled Theories of Corporate Governance: The Philosophical Foundations of Corporate Governance.

8. See generally Karl Polanyi, Our Obsolete Market Mentality, 3 COMMENTARY 109, 109-17 (1947), reprinted in PRimitive, ARChaiC AND MOdERn ECONOMIES: ESSAYS OF KARL POLANYi 59, 68-77 (George Dalton ed., 1968).

9. KARL Polanyi, The GREAT TRANSFORMation 68-77 (1944). 
Financial crises, scandals, and shortcomings testify against the unholy trinity of market, property, and shareholder value. Instead of assuring ever-progressive advances in economic and social welfare, shareholder value proves to raise unaddressed issues of stability and fairness. Enterprises that were its glorious forerunners, such as Enron and Lehman Brothers, have generated material and fraudulent losses, encountering evergreen troubles of sustainability, responsibility, and accountability. The magic of financial markets turned to be black. Mark-to-market accounting, claimed to be "fair" value, was suddenly dismissed once market prices disruptively decreased and financial markets experienced systemic failures. ${ }^{10}$ Accordingly, many scholars have recently acknowledged that reforms are necessary to protect stakeholders, including shareholders, but also human community and nature at large.

Together with regulatory and organizational changes, new beliefs and ideas addressed in this paper were crucial in the ascension of the shareholder value rhetoric. Remedying the current impasse, then, may require not only careful exercises in regulatory reform and policymaking, but also some theoretical upgrades. The misguided understanding of what securities markets and firms are, or should be, has framed received policies and the entire concern with "corporate governance."

This Article engages this theoretical challenge by drawing upon the concept of the firm as an "enterprise entity," which has significant implications for governance and disclosure. It argues that the enterprise entity is a comprehensive approach to the firm that integrates accounting, economics, and law, thus improving on the received understanding of the firm. Part II discusses a framework based on the concept of the firm as an enterprise entity. Part III then contrasts this framework with three alternative views on the firm that jointly constitute the shareholder value rhetoric: the "black box," the "proprietor-entrepreneur," and the "legal person." Further, these views are criticized as "daydreams." Finally, Part IV applies this comparative assessment to matters of corporate governance and disclosure, clarifying the novel approach to governance and disclosure of the business firm.

10. On October 3, 2008, the so-called "Financial Institutions Bailout Bill," also known as the "Paulson Plan," included two sections-132 and 133-relating to fair-value (mark-to-market) accounting. The first gave authority to the SEC to suspend this method of accounting for reasons of public interest and investor protection. The second section mandated further studies on its effects on balance sheets of firms, its impact on the quality of financial information, its role on bank failures in 2008, the process used by the Financial Accounting Standards Board (FASB) in developing related accounting standards, advisability and feasibility of modifications to such standards, and alternative accounting standards to those already in place concerning fair value. European Union authorities took analogous decisions. 


\section{THE FIRM AS AN ENTERPRISE ENTITY}

The idea of the firm as an enterprise entity implies a comprehensive approach that integrates accounting with economics and law, as the notion of entity is already common to all three disciplines and practices. ${ }^{11}$ This approach comprehends the firm as a managed, dynamic system, jointly constituted by two basic relationships as shown in figure 1: the enterprise core, which denotes the management of an economic organization mediated by an accounting system, and its governance, which makes management accountable to various undertaking stakeholders for enterprise income and results (performance).

Figure 1: The Firm as an Enterprise Entity ${ }^{12}$

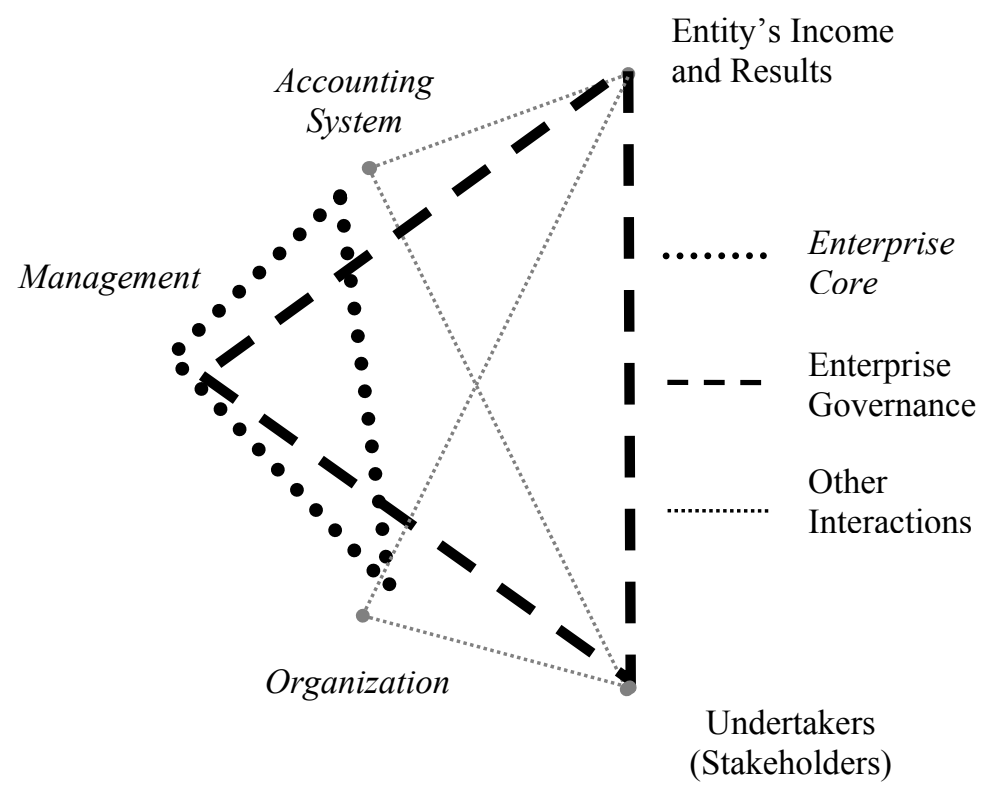

This functional system is characterized by different "structures of production": ${ }^{13}$ institutional, organizational, and epistemic structures. ${ }^{14}$

11. THE Firm as an ENTity: Implications For ECONOMics, ACCOUNTING, AND THE LAW (Yuri Biondi, Arnaldo Canziani \& Thierry Kirat eds., 2007) [hereinafter THE FIRM AS AN ENTITY]; Yuri Biondi, The Firm as an Entity: Management, Organization, Accounting (Università Degli Studi di Brescia, Working Paper No. 46, 2005), available at http://ssrn.com/abstract=774764.

12. Biondi, supra note 11 , at 32 .

13. See generally R.H. Coase, The Institutional Structure of Production, 82 AM. Econ. REV. 713 (1992).

14. See id.; see also Biondi, supra note 11. 
The latter respectively relates to the place and role of institutions, internal organization, and knowledge within the firm. The concept of the enterprise entity aims to frame together these dimensions of the business enterprise. $^{15}$

Theoretically speaking, the entity approach reacts to a "sense of lacking" in the current state of economic theory and practice concerning the firm. Notwithstanding its theoretical and heuristic advances, a market bias can be identified in received approaches to the enterprise activity. This bias leads to an understanding of socioeconomic dynamics on a distinctive individualistic vein, neglecting collective and dynamic dimensions that feature the enterprise activity over time. Conversely, the enterprise entity approach employs insightful suggestions from leading scholars, such as the following: Simon, who addresses the special economic organization of the firm as a dynamic system; ${ }^{16}$ Shubik, who deals with the relationship between accounting and the critique of equilibrium economics of the firm; ${ }^{17}$ Coase, who explores the accounting contribution to the theory of the firm; ${ }^{18}$ and Berle, who criticizes the classical view of the proprietor-entrepreneur under the economic and financial conditions that have characterized firms since the twentieth century. ${ }^{19}$ Moreover, the enterprise entity approach draws upon traditions of thought from economics, accounting, and law that address the business firm and its impact upon economy and society, especially the continental European tradition of accounting and business economics ${ }^{20}$ and old institutional economics developed both in the United States and Europe. ${ }^{21}$ All together, these theoretical perspectives offer a solid background for understanding the firm as an entity: a whole, dynamic system. Accordingly, the firm is then (1) understood as an enterprise entity (dynamic system), (2) characterized by a specific economic and monetary process, which (3) generates incomes to the firm, (4) while being confronted with the actual dynamics

\footnotetext{
15. Biondi, supra note 11

16. See generally Herbert A. Simon, Organizations and Markets, reprinted in THE FIRM AS AN ENTITY, supra note 11, at 54.

17. See generally Martin Shubik, Accounting and its Relationship to General Equilibrium Theory, reprinted in THE FIRM AS AN ENTITY, supra note 11, at 73.

18. See generally Ronald H. Coase, Accounting and the Theory of the Firm, reprinted in THE FIRM AS AN ENTITY, supra note 11, at 82.

19. See generally Adolf A. Berle, Jr., The Impact of the Corporation on Classical Economic Theory, reprinted in THE FIRM AS AN ENTITY, supra note 11, at 92; Adolf A. Berle, Jr., The Theory of Enterprise Entity [hereinafter Berle, The Theory of Enterprise Entity], reprinted in THE FIRM AS AN ENTITY, supra note 11, at 186.

20. ACCOUNTING AND Business ECONOMICS: INSIGHTS FROM NATIONAL TRADITIONS (Yuri Biondi \& Stefano Zambon eds., 2012).

21. See generally THE FIRM AS AN ENTITY, supra note 11. For references to recent advances, see infra Part V (concluding).
} 
and complexity of socioeconomic reality (unfolding and undetermined). ${ }^{22}$

The entity approach has implications for corporate systems of governance and disclosure. ${ }^{23}$ Significantly, accounting systems are integral parts of the institutional framework of the enterprise entity, demonstrating the joint implications of economic, accounting, and legal matters within the firm. In an enterprise affair fraught with unfolding changestogether with asymmetries of resources, access, control, and information-the accounting system copes with the economic and monetary process generated by the whole enterprise over time, defining the representation of entity capital (assets and liabilities) and income (revenues and costs). In this way, the accounting system allows this special process to exist and function autonomously from, and interactively with, shareholding and trading. Thus, accounting systems lie at the core of the continuity and sustainability of the enterprise entity, mediating immanent conflicts of interests among various stakeholders, including shareholders. $^{24}$

This comprehensive understanding of the firm as an enterprise entity contrasts with the shareholder value rhetoric, which frames the firm with securities markets and ownership rights. A market basis reduces the whole firm to a "black box," while an ownership basis submits it to a lonely proprietor-entrepreneur or an autocratic "legal person." The following part provides a comparative analysis of these four approaches to the socio-economy of the business firm.

\section{BEHIND SHAREHOLDER VALUE RHETORIC}

The view of the firm as an enterprise entity contrasts with three alternative views that jointly compose the shareholder value rhetoric. The firm is either made entirely dependent on external markets (especially securities markets), or framed with, and submitted to inside ownership rights or outside legal order as shown in table 1 below. Overall, this rhetoric entirely submits the economy of the firm to the primacy of shareholders, as stated by an accounting scholar quoting Milton Friedman in the 1960s:

22. See Biondi, supra note 11.

23. See generally THE FIRM AS AN ENTITY, supra note 11; Yuri Biondi, What Do Shareholders Do? Accounting, Ownership and the Theory of the Firm: Implications for Corporate Governance and Reporting, 2 ACCT. ECON. \& L. 1 (2012).

24. Yuri Biondi, The Problem of Social Income: The Entity View of the Cathedral, 34 SeAtTLE U. L. REV. 1025 (2011) [hereinafter Biondi, The Problem of Social Income]; Yuri Biondi, The Pure Logic of Accounting: A Critique of the Fair Value Revolution, 1 ACCT. ECON. \& L. 1 (2011) [hereinafter Biondi, The Pure Logic of Accounting]. 
[Vol. 36:391

The proprietary concept [of the firm] seems to personify the traditional, classical ideology of capitalism. This is reflected in a statement by the economist, Milton Friedman, a prominent advocate of that ideology, when he decries the concept of social responsibility that many corporate officials "profess" to have adopted: "Few trends could so thoroughly undermine the very foundations of our free society as the acceptance by corporate officials of a social responsibility other than to make as much money for the stockholders as possible." 25

He further states that " $[\mathrm{t}]$ he corporation is an instrument of the stockholders who own it." ${ }^{26}$ Friedman can be taken as one influential epigone of the tradition of thought already criticized by Karl Polanyi in its general premises and implications. ${ }^{27}$ In this way, the shareholder value rhetoric has disseminated distinctive daydreams that table 1 summarizes and compares with the enterprise entity approach advocated in this Article. These daydreams are dissipated in the following comparative analysis.

25. Reginald S. Gynther, Accounting Concepts and Behavioral Hypotheses, 42 ACCT. REV. 274, 279 (1967) (quoting MiLTON FRIEDMAN, CAPITALISM AND FREEDOM 133 (1962)).

26. Id. (quoting FRIEDMAN, supra note 25).

27. Jean-Philippe Robé, Being Done with Milton Friedman, 2 ACCT. ECON. \& L. 1 (2012). 
Table 1: Four Distinctive Views of the Firm

\begin{tabular}{|l|l|l|l|l|}
\hline & $\begin{array}{l}\text { Enterprise } \\
\text { entity }\end{array}$ & Black Box & $\begin{array}{l}\text { Proprietor- } \\
\text { Entrepreneur }\end{array}$ & $\begin{array}{l}\text { Legal } \\
\text { Person }\end{array}$ \\
\hline $\begin{array}{l}\text { Basic } \\
\text { Concept }\end{array}$ & $\begin{array}{l}\text { A complex } \\
\text { dynamic sys- } \\
\text { tem or whole }\end{array}$ & $\begin{array}{l}\text { A shallow } \\
\text { nexus of } \\
\text { (market) } \\
\text { prices or } \\
\text { (complete) } \\
\text { contracts }\end{array}$ & $\begin{array}{l}\text { Ownership } \\
\text { and wealth }\end{array}$ & $\begin{array}{l}\text { Analogy } \\
\text { with human } \\
\text { persons }\end{array}$ \\
\hline Functioning & $\begin{array}{l}\text { A specific } \\
\text { economic and } \\
\text { monetary } \\
\text { process }\end{array}$ & $\begin{array}{l}\text { A mechanical } \\
\text { link between } \\
\text { price and cost } \\
\text { for each prod- } \\
\text { uct separately } \\
\text { (marginal cost } \\
\text { pricing) }\end{array}$ & $\begin{array}{l}\text { A legal and } \\
\text { economic } \\
\text { device for the } \\
\text { solitary owner }\end{array}$ & $\begin{array}{l}\text { Autocratic } \\
\text { (plutocratic) } \\
\text { organization } \\
\text { with incor- } \\
\text { porated } \\
\text { duties and } \\
\text { rights }\end{array}$ \\
\hline Purpose & $\begin{array}{l}\text { Generation of } \\
\text { income to the } \\
\text { firm, related } \\
\text { to the satisfac- } \\
\text { tion of indi- } \\
\text { vidual and } \\
\text { social needs }\end{array}$ & $\begin{array}{l}\text { A unique } \\
\text { objective of } \\
\text { "profit maxi- } \\
\text { mization" }\end{array}$ & $\begin{array}{l}\text { A unique } \\
\text { objective of } \\
\text { generation of } \\
\text { rents from } \\
\text { wealth }\end{array}$ & $\begin{array}{l}\text { A unique } \\
\text { objective of } \\
\text { self- } \\
\text { perpetuating } \\
\text { generation } \\
\text { of profits } \\
\text { and rents }\end{array}$ \\
\hline $\begin{array}{l}\text { Under actual } \\
\text { dynamics and } \\
\text { complexity of } \\
\text { socio- } \\
\text { economic } \\
\text { reality (un- } \\
\text { folding and } \\
\text { undetermined) }\end{array}$ & $\begin{array}{l}\text { Under ideal- } \\
\text { ized condi- } \\
\text { tions ab- } \\
\text { stracted away } \\
\text { from hazard } \\
\text { and context }\end{array}$ & $\begin{array}{l}\text { Under ideal } \\
\text { conditions of } \\
\text { complete } \\
\text { contracting } \\
\text { and enforce- } \\
\text { ment }\end{array}$ & $\begin{array}{l}\text { Under ideal } \\
\text { conditions } \\
\text { of complete } \\
\text { legal order } \\
\text { and en- } \\
\text { forcement }\end{array}$ \\
\hline Conditions
\end{tabular}

\section{A. Daydreaming of the Firm as a "Black Box"}

Some endorsers of shareholder value more or less explicitly refer to the conception of the firm as a "black box." This view points to a neoclassical economic posture that pretends to understand the firm on a market basis; the inner intricacies of the business are "blacked out" to those outside, while external market prices for inputs (including fictitious 
commodities such as land, money, and human work) and outputs capture the economic and monetary process of the firm. In fact, the history of economic thought sheds some light into this no-longer-empty box. On the contrary, this market approach to the firm provides a peculiar understanding based upon (1) a shallow nexus of (market) prices or (complete) contracts, characterized by (2) a mechanical link between price and cost for each product separately (marginal cost pricing), and (3) a unique objective of "profit maximization"- a profit that shall result to be null, like in the punishment of Tantalus, ${ }^{28}$ (4) under idealized conditions abstracted away from time, hazard, and interaction. ${ }^{29}$

This set of assumptions allows the firm as such to vanish in a system of efficient market pricing. The whole firm no longer has any role in economy and society. Indeed, what about corporate governance and social responsibility of its management? If managers should disclose information about their activity and the business incomes generated, they may discharge their responsibility upon markets that they must follow. Markets, especially the share exchange, are then at the core of the economics of the firm.

\section{B. Daydreaming of the Firm as a Proprietor-Entrepreneur}

Some advocates of shareholder value argue for another daydream, which understands the firm as a legal-economic device of its proprietorentrepreneur. ${ }^{30}$ This time, the firm disappears in favor of this lone captain of his own business. This capitalistic hero alone bears the risks, undertaking the management of the entire enterprise. The firm and its personnel are nothing but his instruments, playing no role in decision making, organization, or control, because the solitary owner is all that matters. This approach understands the firm as the following: (1) a form of ownership and wealth, providing (2) a legal and economic device for the

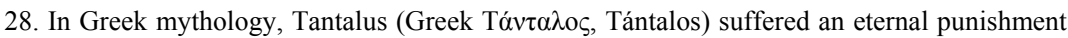
in Tartarus. Tantalus was made to stand in a pool of water beneath a fruit tree with low branches with the fruits ever eluding his grasp and the water always receding before he could take a drink. He was the son of the nymph Plouto ("riches," as in gold and other mineral wealth) and the grandchild of Chthonia ("Earth"). From the name "Tantalus" originates the English verb "to tantalize."

29. Shubik, supra note 17; see also Martin Shubik, A Note on Accounting and Economic Theory: Past, Present, and Future, 1 ACCT. ECON. \& L. 1 (2011).

30. We must insist here on the presence of only one entrepreneur or a mythical existence of one universal and fully homogeneous class of them, because absent such an individualistic and reductionist assumption, the presence of several heterogeneous proprietor-entrepreneurs would include an interactive and holistic dimension that this approach purposefully excludes and is unable to deal with. Lynn Stout masterfully explains this concept in her article New Thinking on "Shareholder Primacy,” 2 ACCT. ECON. \& L. 1 (2012). See also Jack Hirshleifer, Investment Decision Criteria, in The New Palgrave: A Dictionary OF ECONOMics (John Eatwell, Murray Milgate \& Peter Newman eds., 1987). 
solitary owner, (3) with a unique objective of generating rents from that wealth, (4) under ideal conditions of complete contracting and perfect enforcement.

Once again, the firm as such disappears in a system of fully enforceable ownership rights. The whole firm has no role in economy and society. Concerning governance and social responsibility of its management, the latter may discharge any responsibility upon the owner, whom it must obey. Thus, ownership is at the core of the economics of the firm under this approach.

\section{Daydreaming of the Firm as a "Legal Person"}

A further daydream understands the firm as an artificially created legal person having its own life, including citizenship rights, like a citizen that is a human being. ${ }^{31}$ This self-serving giant runs its business in a world of pure law. All that matters then is this solitary legal person artificially incorporated by law or statute. This viewpoint understands the firm as (1) a self-standing holder of ownership and wealth and (2) an autocratic owner and decision maker, (3) with a subjective objective of whatever the legal person wants under law or statute, (4) in a world of pure law entirely comprised by, and reduced to, those laws and statutes.

This approach is often associated with the proprietor approach. As stated by an accounting scholar in the 1950s, "[t]hose who believe the accounting entity should be personified are known as the proprietary theorists, and those who believe that the entity should not be personified are known as the entity theorists." 32

Here, ownership is understood through an outside legal order established by laws and statutes, instead of an inside legal order based upon ownership rights. But, as usual, the firm disappears in this framework, reduced to an artificial person that legally exists as human beings do. If management of this person should disclose information about its activity and the business incomes generated, it may discharge any responsibility upon that person whom it must obey. The firm is then reduced to one of its legal forms, the corporation, which becomes an "island of absolute

31. See, e.g., Yuri Biondi, The Enterprise Entity and the Constitution of the American Economic Republic, 1 AcCT. ECON. \& L. 1 (2011).

32. Walter G. Kell, Should the Accounting Entity be Personified?, 28 AccT. REV. 40, 42 (1953). John R. Commons refuted the personification of the going concern that constitutes the basic unit of analysis in his institutional economics: "The false analogies may be condensed into three analogies of mechanism, organism, and personification, since they consist in transferring to economics the ideas properly employed in physics, physiology, or individual psychology. These, we conceive, may be avoided by substituting the two ideas of transactions and going concerns." JOHN R. COMMONS, Institutional ECONOMiCs: Its PLACE In POLITICAL ECONOMY 96 (1934). 
power." 33 Considering that corporate law usually grants decision making collectively to shareholders and their fiduciary delegates, the way is then paved to a plutocracy that is problematic in a socioeconomic republic. ${ }^{34}$

\section{The Problems with Daydreams Driven by Shareholder Value}

However influential and significant these daydreams are, they involve problems that go beyond the emotional (and political) reactions for or against them. These views are at odds with the reality of business firms as they exist and function in our economy and society. For instance, firms combine a number of corporate and other legal arrangements (including contracts and regulations concerned with labor, investor protection, financial securities, foods and drugs, environment, and antitrust). These arrangements jointly generate the triple separation between ownership, control, and management (not only the separation between ownership and control that is recently stressed) that Berle and Means already recognized in their seminal work. ${ }^{35}$ To work through this legaleconomic web, management does not, and cannot, rely exclusively on outside market pricing, but maintains accounting systems that are modes of looking inside the ongoing enterprise process fraught with time, hazard, and interaction. Accounting systems, not price systems, enable actors-management, stakeholders, and regulators - to know, organize, or govern that process.

Widespread conceptions of the black box, the proprietorentrepreneur, and the legal person contrast with this special legal and accounting field generated by the enduring economy of the business firm. Specifically, law and accounting provide evidence for the functional distinction between the firm and its alleged "owners." The legal structure of the firm involves a number of various legal forms (including corporations) that hold and possess resources, enter into contracts and

33. See R.H. Coase, The Nature of the Firm, 4 ECONOMICA 386, 388 (1937) (“As D.H. Robertson points out [in the Control of Industry], we find 'islands of conscious power in this ocean of unconscious co-operation like lumps of butter coagulating in a pail of buttermilk."”).

34. A predatory plutocracy was stigmatized by Thorstein Veblen and Adolf A. Berle, Jr. Berle wrote:

'[A]bsolute control' ... [ [of corporations without property] was part of the plutocratic age which prevailed through the last three decades of the nineteenth and the first decade of the twentieth century, leaving a reminiscent mark on the culture of the United States.... Perhaps there is a passing recrudescence of the era in Texas, due chiefly to certain accepted loopholes in income tax law, to fortunate oil discoveries, and to a mass upsurge in need for petroleum.

Adolf A. Berle, Jr., Power Without Property: A NeW Development in American POLITICAL ECONOMY 72-73 (1959).

35. See generally Adolf A. Berle, Jr. \& Gardiner C. MEAns, The Modern Corporation AND PRIVATE PROPERTY (1932). 
obligations, and have priority rights and control on flows, incomes, and results. ${ }^{36}$ Furthermore, through the accounting system, prudential regulation and investor protection restrict dividend payments and equity repayments from the firm to its shareholders or partners. Through this same system, fiscal regulation establishes the basis for income tax that is determined and eventually paid out before net earnings are shared between shareholders and partners. ${ }^{37}$ Therefore, ownership by isolated individuals is framed and shaped by a "phantom" entity that the idea of a "solitary owner" cannot cope with. ${ }^{38}$

In this context, the legal person transforms that phantom into a "Frankenstein incorporated." 39 But a republican order establishes corporations and other legal entities as intermediary bodies that are objects, not subjects, of the law. ${ }^{40}$ The legal person idea conflicts with constitutional features of these bodies. In particular, the legal structure of firms comprises, or is disintegrated by, a myriad of legal entities and other legal devices, which makes it hazardous to identify that person, even if artificial. These socioeconomic wholes submit a legal order, voluntarily and compulsorily regulated by consent and the law. Specifically, they integrate the polity through a system of collective and continued decision making governed by fiduciary representatives who run and supervise those bodies on behalf of their constituencies, including shareholders in the case of corporate law. Indeed, these bodies respond and are submitted to a variety of inside and outside checks and balances to assure their consistent and continued role in economy and society. In sum, while legal personality is a convenient legal device (or object) that is properly framed and shaped by private and public orderings, the idea of an artificially created legal person is inconsistent with the integration of the firm into the institutional framework of economy and society.

\footnotetext{
36. For example, any shareholder that used a corporate car for a day would likely be arrestedquite a peculiar owner's right in the firm indeed.

37. Reuven Avi-Yonah, Taxation, Corporate Social Responsibility and the Business Enterprise (Comprehensive Research in Law \& Political Econ., Working Paper No. 19, 2009) (discussing the legal-economic foundations of taxation under different conceptions of the business firm); see also Henrik J. Kleven, Claus T. Kreiner \& Emmanuel Saez, Why Can Modern Governments Tax So Much? An Agency Model of Firms as Fiscal Intermediaries (Nat'l Bureau of Econ. Research, Working Paper No. 15218, 2009).

38. Longstanding legal debates on the nature of public corporation deal with this issue, which depends on a misleading focus on individual entrepreneurship and ownership. The notion of the enterprise entity aims to encompass these debates by understanding the legal structure of the firm as a system of multiple legal arrangements including, but not limited to, corporations. See generally Berle, The Theory of Enterprise Entity, supra note 19; Kurt A. Strasser \& Phillip Blumberg, Legal Form and Economic Substance of Enterprise Groups: Implications for Legal Policy, 1 ACCT. ECON. \& L. 1 (2011).

39. I. MAURICE WORMSER, FRANKENSTEIN, INCORPORATED (1931).

40. Biondi, supra note 31.
} 
Just as the legal person daydream is contrary to the reality of the firm as an entity, the black box idea does not capture the entity phantom. This view assumes that the price system (the market) is sufficient to represent, organize, and govern the business activity of firms. The firm is then supposed to be neutral to socioeconomic dynamics; institutions should not matter in the enterprise field. Accordingly, no enterprise inflows and outflows would exist except for efficient market prices.

In fact, the firm and its dynamics do matter in the economic and monetary process. They generate a socioeconomic field that frames and shapes the ongoing generation of income that all stakeholders, including shareholders, have interests in. ${ }^{41}$ Representation, organization, and governance of this enterprise process require an accounting system, not a price system, because the accounting system defines economic revenues and costs attached to the reference period through "accruals," the determination of the accounting entity perimeter, the retained concept of capital maintenance, and other technicalities that encompass the monetary dimension. Contrary to the black box view, the firm cannot be reduced to a simplistic "nexus of monetary flows (prices)" because the accounting system goes far beyond the cash basis through its definition and application of accruals, consolidation, and other accounting technicalities. ${ }^{42}$

Moreover, prior financial literature has argued for the impact of taxation and dividend policies on shareholder value. ${ }^{43}$ In fact, accounting systems provide the basis of taxation and dividend distribution. This accounting basis is not a market basis; rather, it enables the accounting system to establish gross and net earnings through revenues and expenses, as well as assets and liabilities. These earnings may be partly or fully distributed to shareholders or partners, and provide the basis to determine enterprise income taxation, maintenance of prudential reserves, allowance of executive compensation, and so forth. ${ }^{44}$ All stakeholders, including shareholders, jointly hold interests in, and eventually expect to be satisfied through, this income.

Thus, the accounting system provides a common representation of business capital and income to the firm, which becomes a joint concern over time. The accounting system structures this enterprise process of becoming through time, establishing the firm as an enterprise entity. This

41. Shyam Sunder, Extensive Income and Value of the Firm: Who Gets What? (Comprehensive Research in Law \& Political Econ., Working Paper No. 20, 2009).

42. Biondi, Money Without Value, supra note 5.

43. See generally M.J. Gordon, Dividends, Earnings, and Stock Prices, 41 REV. ECON. \& StAT. 99 (1959); John Lintner, Distribution of Incomes of Corporations Among Dividends, Retained Earnings, and Taxes, 46 AM. ECON. REV. 97 (1956); Franco Modigliani \& Merton H. Miller, Corporate Income Taxes and the Cost of Capital: A Correction, 53 AM. ECON. REV. 433 (1963).

44. See generally Biondi, supra note 23. 
enterprise process is concerned with uncertainties, bounded knowledge, potential and actual mistakes, and disorganization. It is unfolding and undetermined. Confronted with this process, the accounting system constitutes a special mode of representing, organizing, and regulating the enduring economic organization and its becoming. It deals with price formation, carried immobilizations (investments), overhead allocation, and all the concerns that are at the core of everyday business activity through time, space, and interaction.

In conclusion, the firm and its accounting system are not reducible to a mere "nexus of market prices" based upon tradable ownership rights. On the contrary, the accounting system constitutes an integral part of the "institutional structure of production," which can no longer be reduced to markets, ownership, and legal forms alone. This approach leads to an understanding of the firm as an enterprise entity that is functionally shaped by the relationship between management, organization, and the accounting system. Together, these constituents play an active role in the economic and monetary process of creating and allocating resources (production and distribution of wealth), along with accounting, mapping, and mediating enterprise processes that link organization and management with the enterprise field. This understanding has significant implications for corporate governance and disclosure, which are discussed in the following part.

\section{GOVERNANCE AND DISCLOSURE OF THE FIRM AS AN ENTERPRISE ENTITY}

Notwithstanding the factual problems with market and ownership views mentioned above, we are free to pretend that either markets or shareholders should dominate firms, and we should take full responsibility for the consequences of this choice. In fact, this has been the main attitude for the last three decades of corporate governance and regulation. For instance, an ownership view has been the basis of converging conceptual frameworks of financial reporting established by the Financial Accounting Standards Board (FASB) in North America and the International Accounting Standards Board (IASB). In defining financial instruments with characteristics of equity, ${ }^{45}$ FASB states the following:

\footnotetext{
45. Fin. ACCOUNTING StANDARds Bd., PreliminARY Views: FinANCIAL InSTRUMENTS With CHARACTERISTICS OF EQUITY (2007). Through a joint project on liabilities and equity, the FASB and IASB are seeking to address unresolved issues concerning classifying financial instruments as equity or liabilities. As part of this process, the FASB issued its report, Preliminary Views: Financial Instruments with Characteristics of Equity, describing three possible approaches - basic ownership, ownership settlement, and reassessed expected outcomes-and from these selected the basicownership approach. Id. at iii.
} 
[A]n instrument would be classified as equity if it (1) is the most subordinated interest in an entity and (2) entitles the holder to a share of the entity's net assets after all higher priority claims have been satisfied. The holders of equity instruments are viewed as the owners of the entity .... The underlying principle of the basic ownership approach is that claims against the entity's assets are liabilities (or assets) if they reduce (or enhance) the net assets available to the owners of the entity. ${ }^{46}$

As Jensen candidly argues, "[i]n the end, of course, we are all interested in normative questions; a desire to understand how to accomplish goals motivates our interest in these methodological topics and in positive theories." ${ }^{\text {"47 }}$ Milton Friedman's "what if" argument may also be offered as a defense of this normative attitude. ${ }^{48}$ Still, while a theory is obviously concerned with what is and what should be, it also concerns what can be. Whether it has some predictive power or not, a theory's overall framing of facts and potentials is critical whenever recommendations on alternative actions and alternative regulatory regimes are under consideration. Otherwise, poor policies may result, thus dampening economy and society.

Contrary to shareholder value rhetoric, financial crises, scandals, and shortcomings suggest that a market- and ownership-based approach to the firm provides limited understanding. Its theoretical choice to ignore the firm has eventually transformed it into an unaddressed field of overwhelming power. Consequently, the firm, as a phantom, haunts the socioeconomic realm, and headlines reporting massive shortcomings reveal how powerful this phantom can be.

Advocates of shareholder value have been concerned with public (governmental) powers, ${ }^{49}$ but private (financial) powers can also raise legitimate economic and societal concerns. It is astonishing to see how recent neoliberal thinking criticizes governmental intervention, ignoring private power use and abuse. But should a liberal perspective seek to protect individuals from powers, both public and private? Should it prioritize human liberty, autonomy, and justice over laissez-faire in eco-

46. Id.

47. Michael C. Jensen, Organization Theory and Methodology, 58 ACCT. REV. 319, 320 (1983).

48. See generally Milton Friedman, Essays in Positive Economics (1953). For criticism on this epistemological position, see Robert N. Anthony, The Trouble with Profit Maximization, in THE FIRM AS AN ENTITY, supra note 11, at 186; Robert S. Kaplan, Comments on Wilson and Jensen, 58 ACCT. ReV. 340 (1983); Herbert A. Simon, Discussion: Problems of Methodology, 53 Am. ECON. REV. 229 (1963); Herbert A. Simon, Rational Decision Making in Business Organizations, 69 AM. ECON. REV. 493 (1979).

49. Ugo Mattei \& Laura NAder, Plunder: When the Rule of LAW IS Illegal 42 (2008); Andrei Shleifer, State Versus Private Ownership, 12 J. ECON. PERSP. 133 (1998). 
nomic affairs? Liberal thinkers have legitimately called for institutions to regulate the polity in order to generate a socioeconomic order that accommodates the immanent divergence and conflicts of interest among individuals. Private and public orderings combine to generate governance and regulation that cannot merely be reduced to governmental intervention, while "deregulation" has no meaning in this context.

It is misleading to adopt a theoretical view that excludes, by assumption, immanent and potential problems that can occur and should be addressed. This was the case with equilibrium approaches to financialmarket dynamics. ${ }^{50}$ This is the case with current approaches to the theory of the firm as well. In contrast to the voluntary myopia that shareholder value rhetoric defends, the view of the firm as an enterprise entity takes the firm seriously. Pursuant to this view, governance and regulation of business firms are upgraded from a logic of ownership and securities markets to one of accountability, ${ }^{51}$ where the institutional framework is designed and enforced to assure this accountability. The firm as such no longer disappears from the economy and society; rather, it plays an active role in the process of creation and allocation of resources. ${ }^{52}$ Indeed, what about corporate governance and the social responsibility of its management? Management controls ongoing business activities and business incomes generated by the enterprise entity under its fiduciary responsibility; accounting systems are a key mode of this control. Under this approach, management of the enterprise entity is the economic core of the business firm, with significant implications for enterprise governance and disclosure.

50. Margaret M. Blair, Making Money: Leverage and Private Sector Money Creation, 36 Seattle U. L. ReV. 417 (2013); see Yuri Biondi, Money Without Value, supra note 5; Alan Kirman, The Intrinsic Limits of Modern Economic Theory: The Emperor Has No Clothes, 99 ECON. J. 126 (1989); see also Herbert A. SimON, AN EMPIRICAlly BASEd Microeconomics (1997); Shubik, supra note 17; Masanao Aoki \& Hiroshi Yoshikawa, The Nature of Equilibrium in Macroeconomics: A Critique of Equilibrium Search Theory, 3 ECON.: OPEN-ACCESS, OPEN-ASSESSMENT EJOURNAL 37 (2009), http://dx.doi.org/10.5018/economics-ejournal.ja.2009-37.

51. As a matter of fact, these three logics interact simultaneously in the actual field of the business firm, constituting dynamic sources of tension, conflict, and transformation. Here, we are theoretically arguing for a preference or hierarchy between them as a focus and principle of reference. See Marc T. Moore \& Antoine Reberioux, Unearthing the Institutional Roots of AngloAmerican Corporate Governance, 40 ECON. \& SOC'Y 84 (2011).

52. In a neglected paper, Gardiner Means explains stagflation - the simultaneous presence of inflation and recession, including unemployment, in the macro-economy-with corporate power and its "exercise of pricing discretion." Gardiner C. Means, Corporate Power in the Marketplace, 26 J.L. \& ECON. 467, 476 (1983). 


\section{A. Implications of the Enterprise Entity View for Governance and Disclosure}

In recent decades, governance and disclosure have been driven by shareholder value rhetoric, ${ }^{53}$ which in turn relies on securities markets and ownership for control. The "institutional structure of production" is then expected to make shareholder power over corporate governance and disclosure both operational and enforceable. However, even if coupled with securities trading, ownership still cannot grasp the whole institutional structure of production. This structure is concerned with sustainability, accountability, and responsibility within the special field generated by the ongoing business firm. Accounting systems are an integral part of this structure because they make the firm and its management accountable. In this context, accounting becomes a way to represent, organize, and regulate the dynamic system of the business firm. Even in the complete absence of markets and ownership (and their alleged control over management), accounting systems assume an active role in representing, organizing, and governing the ongoing activities of the enterprise entity as a whole.

In turn, the firm itself constitutes a socioeconomic field fraught with unfolding changes and asymmetries of resources, access, control, and knowledge among different stakeholders, including shareholders, and management. This field involves temporal, interactive, and holistic concerns that cannot be addressed on individual or contractual bases. In a world of pure law, every business activity can be controlled ex ante by external forces driven by immediately enforceable rules and contractual claims. This is strikingly analogous to the world of perfect and complete markets, where outside market prices suffice to secure the socioeconomic interests of each stakeholder committed to the business enterprise, where every business activity would be controlled ex ante by external forces driven by the price mechanism and monetary incentives. In contrast, in the world of complex organizations concerned with unfolding changes and limited rationality, every ongoing entity involves a financialeconomic core existing beneath the transactions formalized in contracts and payments.

53. Yuri Biondi \& Isabelle Chambost, Gouvernance, Transparence et Encastrement Cognitif des Marchés Financiers: Le Cas des Analystes Financiers [Governance, Transparency and Cognitive Embeddedness: The Case of Financial Analysis], Revue FrançAise DE Gouvernance D'EnTREPRISE, Apr. 2009; Yuri Biondi \& Antoine Reberioux, The Governance of Intangibles: Rethinking Financial Reporting and the Board of Directors, 36 АсСт. F. 279 (2012), available at http://www.sciencedirect.com/science/article/pii/S0155998212000221 (presented to the IPR Conference, "Governance, Intangibles \& Corporate Social Responsibility," in Collegio S. Chiara, University of Siena, on September 29, 2008). 
Within this financial-economic core, contracts are necessarily incomplete, and markets (when they exist) are never perfect. In this void, the firm acquires a dynamic and collective dimension that generates a field of power. ${ }^{54}$ As Berle recognized early on, legalistic reasoning cannot deal with this power because the formal conformity to rules may hide unfair behavior, fraud, and abuses. ${ }^{55}$ This situation is at the very root of the legal-economic concept of "equitable interest," that is, a legitimate interest that the bearer might be unable to defend through contractual enforcement of rights and claims. ${ }^{56}$ The institutional system of protection-comprising governance and regulation-fills this void so as to address the "equitable interests" of stakeholders, including shareholders, relying on the firm for the joint accomplishment of goals, but substantially, though not formally, lacking contractual enforcement by courts or market outward options. Public and private orderings combine then to balance the interests of shareholders with those of other stakeholders, and to protect those interests along with the continuity of the business enterprise over time. This approach provides managers and judges with a clue to comprehend the socioeconomic dynamics of the joint concern as "fair" business conduct because it takes into account "other people's interests." $" 57$

From this perspective, the institutional structure (including its accounting system) enters into the firm's field as an accountability device concerned with sustainability and responsibility of the joint-business affair over time. This enterprise entity approach guides the institutional analysis of the firm: (1) the entity is a "joint and becoming concern, autonomous from stakeholders (including shareholders); ${ }^{58}$ (2) there is separation between ownership and control, control and management, and management and ownership; (3) "[a]bsentee ownership" (and the difference between the legal and economic frontiers) applies; (4) [a]ccounting systems play a definite role in the enterprise process; and (5) accounting

54. The Firm AS An Entity, supra note 11; Sadao Takatera \& Norio Sawabe, Time and Space in Income Accounting, 25 ACCT. ORG. \& SOC'Y 787 (2000).

55. THE FIRM AS AN ENTITY, supra note 11.

56. See generally Sabine Montagne, Les Fonds de Pension: Entre Protection Sociale et SPECUlation FinANCiERE 46 (2006) (dealing with the emergence of the notion of "equity" and "equitable interest" in trust regulation).

57. According to Adam Smith, the management of the affairs of a public company is concerned with "other people's money," and this may eventually lead to negligence and profusion. ADAM SMith, THE INQUiRY INTO THE NATURE AND CAUSES OF THE WEALTH OF NATIONS 439 (1776).

58. This concept expands upon the notion of "going concern" that John R. Commons distilled from legal-economic practices as a theoretical keystone of his institutional economics. The notion of going concern was stressed by early accounting-entity theorists at least until the sixties. $C f$. Biondi, supra note 23 . 
systems further distinguish this enterprise process from, and articulate it with, the value (and valuation) of shareholders' equity shares.

For matters of governance and disclosure, the enterprise entity constitutes a "joint and becoming concern" (point 1). Some legal and economic features define economic autonomy and continuity of the firm. In particular, shareholders have limited financial liability and benefit from an unconstrained right of "exit," while prior legal protection is granted to other stakeholders against shareholders in some circumstances. Moreover, through its legal structure - comprising a variety of legal forms and arrangements, including corporations, vehicles, mandates, and fiduciary duties - the entity acquires legal capacity to enter into contracts and obligations, to hold autonomous (collective) property, and to possess assets, and it has priority in controlling cash flows, incomes, and results. These features contribute to separate shareholding from the corporation that issued those shares, as well as to separate the corporation from the whole business enterprise. ${ }^{59}$ Additionally, enterprise groups feature the financial structure and reinforce both separations. ${ }^{60}$ Together, these separations point to the distinction between shareholding on the one hand, and management (namely possession) on the other. Only management is entitled to dispose of assets and cash flow, and to organize the activity of the business enterprise (point 2). In turn, this managerial power (or autonomous decision making) requires an institutional system of control for regulation and supervision. Here, the notion of "absentee ownership" 61 becomes critical (point 3): A large number of shareholders each holding only a small part of shareholder equity, and excluded from relevant decision making, while influential insiders - including significant minority shareholders, investment funds, and financial intermediaries - can control the firm at a distance by influencing managerial decision making and rule making both inside and outside the firm. ${ }^{62}$

In this context, legal forms - related to corporate frontiers-are distinct from the socioeconomic frontiers of the firm, that is, the economic substance of the business enterprise. This is the primary reason for accountants to look beyond legal forms to account for the business enterprise on a more appropriate basis (point 4). In turn, this implies the sepa-

59. Robé, supra note 27.

60. Strasser \& Blumberg, supra note 38.

61. See generally THORSTEIN VEBLEN, ABSENTEE OWNERSHIP (1923); Williams, supra note 3.

62. On the myth of diffuse ownership in the United States and abroad, see AGLIETTA \& REBERIOUX, supra note 7; William W. Bratton \& Michael L. Wachter, Shareholders and Social Welfare, 36 Seattle U. L. ReV. 489 (2013); Julie Froud \& Karel Williams, Private Equity and the Culture of Value Extraction (Cent. for Research in Socio-Cultural Change, Working Paper No. 31, 2007); Clifford G. Holderness, The Myth of Diffuse Ownership in the United States, 22 REV. FIN. STUD. 22 (2009). 
ration between accounting system and the valuation of equity shares (point 5). The reference to value is surely the most insidious issue raised by shareholder value rhetoric. The latter reduces the firm to a security that can be traded among allegedly homogeneous investors at current market prices, which would be the best (or only) way to learn its intrinsic value. "In a volume on economics recently published we find that 'price is a concrete manifestation of value.' We are already familiar with the incarnations of Buddha. To them we are now asked to add the incarnations of Value." 63

The mirage of value overshadows not only the individual features and strategies of idiosyncratic investors but also the connection of every investor to the business firm as a dynamic collective entity. The financial and monetary process generated by the entity is reducible to past and future cash flows, like a slot machine. ${ }^{64}$ But management and governance of an enterprise group producing a range of products and services in dozens of countries and jurisdictions surely require a level of control and representation that is not reducible to share market prices cashed out in trading (if available). ${ }^{65}$ Therefore, instead of broadcasting the firm as a proprietary placement, accounting systems are structured to provide relevant and reliable representation and control of consolidated accounting entities. Furthermore, accounting systems enforce institutional regulations regarding dividend payments and repayments of shareholder equity, provision of regulatory reserves, and retention of net earnings. The institutional role of accounting is reinforced by the fact that the enterprise entity does not have to repay shares at their value-either market or accounting value-until liquidation, while shareholders can exit their investments by selling them through the share exchange. In sum, the institutional structure of the firm acts as a shield, locking in financial resources committed to the firm and required for the continuity of the enterprise over time. ${ }^{66}$ In this context, Fama's rebuttal of the ownership of the firm ${ }^{67}$ is partial, maintaining the "ownership" of financial capital and empowering shareholders as residual claimants. ${ }^{68}$ Blair explains:

63. Vilfredo PAReto, The Mind AND Society 30 n.1 (Andrew Bongiorno \& Arthur Livingston trans., Arthur Livingston ed., 1935) (1906).

64. In a similar vein, the Boston Consulting Group invented the expression "cash cow" to name a business unit that is floridly established in a mature industry.

65. Through his prophetic style, Veblen strives to distinguish technological production and progress, driven by engineering from a cash focus led by financiers, in the business enterprise field. See generally THORSTEIN VEBLEN, THE THEORY OF BUSINESS ENTERPRISE (1904).

66. Margaret M. Blair \& Lynn A. Stout, A Team Production Theory of Corporate Law, 85 VA. L. REV. 247 (1999).

67. Eugene F. Fama explains:

[O]wnership of capital should not be confused with ownership of the firm. Each factor in a firm is owned by somebody. The firm is just the set of contracts covering the way in- 
[S]hareholder value advocates argue ... shareholders act as the residual claimants, and also have certain control rights. So, advocates believe, it is a useful, and not misleading, shorthand expression to call shareholders the 'owners.' The rhetoric of 'ownership,' however, subtly redefines corporations in terms of the presumed property rights of one class of participants in the firm, thereby adding a tone of moral superiority to the idea that corporations should be run in the sole interest of shareholder. . . ${ }^{69}$

However, shareholders own only their own shares, while financial resources are indefinitely committed to the business firm. Until and unless liquidation occurs, shareholders remain creditors to the firm up to the limit of committed financial resources that cannot be withdrawn at will, as J.A. Schumpeter masterfully argued. ${ }^{70}$ Nevertheless, they are allowed to exit their commitment by freely selling their shares. In this way, even in the case of financial distress, they have limited responsibility and may leave the firm before other constituencies with more dependent and specific commitments. On the point, in direct response to Jensen's comments in 1983, Kaplan argues for an entity perspective:

The shareholder, as an owner of property rights in the decision making of the firm, is likely an anachronism at this time. The long-term interests of the corporation are more likely to be vested de facto, but not legally, with the managers, workers, suppliers, customers, and the community of the firm. These economic agents have much more non-diversifiable risk associated with the firm and a longer contractual history that the existing shareholders. ${ }^{71}$

Because the firm cannot be reduced and limited to its shareholders, its relationship with shareholder claims should be addressed and clarified, which is the focus of the next section.

\section{B. The Enterprise Entity and Shareholders' Claims}

The operation of the firm as an enterprise entity frames and shapes its relationship with potential and actual shareholders, including their

puts are joined to create outputs and the way receipts from outputs are shared among inputs. In this 'nexus of contracts' perspective, ownership of the firm is an irrelevant concept.

Eugene F. Fama, Agency Problems and the Theory of the Firm, 88 J. POL. ECON. 288, 290 (1980).

68. Cf. Eugene F. Fama \& Michael C. Jensen, Separation of Ownership and Control, 26 J.L. \&

ECON. 301 (1983); Eugene F. Fama \& Michael C. Jensen, Agency Problems and Residual Claims, 26 J.L. \& ECON. 327 (1983).

69. Blair, supra note 7, at 57.

70. Yuri Biondi, Schumpeter's Economic Theory and the Dynamic Accounting View of the Firm: Neglected Pages from the Theory of Economic Development, 37 ECON. \& SoC'Y 525 (2008).

71. Kaplan, supra note 48, at 343-44 (emphases added). 
remuneration. According to Shleifer and Vishny's narrow definition, "[c]orporate governance deals with the ways in which suppliers of finance to corporations assure themselves of getting a return on their investment[,]"72 in the form of either a market return (capital gains between buying and selling prices), or a comprehensive return including dividends. However, the market value is external to the enterprise process (according to point 5 above), and the distribution of dividends is generally subordinate to, and constrained by, net earnings as determined by the accounting system (point 4 above).

Therefore, shareholder remuneration depends on the status and role of shareholding, its relationship to the firm as an enterprise entity, and further on the shareholder connection to the business-enterprise field. When asking what the firm does and should do for the shareholder, one should conversely ask what the shareholder does and should do for the enterprise. From the viewpoint of the enterprise entity, shareholder equity is a special source of financing. Accordingly, the accounting system may recognize the shareholder's claim on the business income generated by the enterprise entity as a cost and allocation. ${ }^{73}$ Improved accounting techniques-for instance, either a "Shareholders' Equity Interest" based on the actual financial funds provided in the past, or a "Shareholders' Equity Share" of overall net enterprise earnings as established in some jurisdictions - may determine this remuneration, which is already included in management-accounting systems. This method of accounting recognition differs from the definition of shareholder value provided by "Economic Value Added" (EVA) ${ }^{75}$ and other market-based metrics. ${ }^{76}$ Technically speaking, the latter metrics are variants of discounted present value based on prospective cash flows to shareholders. EVA may be formalized as follows:

$$
\begin{gathered}
E V A=(R O E-k) \cdot \text { Shareholders' Equity }= \\
\text { Net Earnings }-k \cdot \text { Shareholders' Equity }
\end{gathered}
$$

The term $R O E$ stands for the usual "Return on Shareholders' Equity" and refers to the annual ratio of net earnings on cumulated shareholders' eq-

72. Andrei Shleifer \& Robert W. Vishny, A Survey of Corporate Governance, 52 J. FIN. 737, 737 (1997).

73. See generally Biondi, supra note 23.

74. ROBERT N. ANTHONY, TELL IT Like it WAS: A CONCEPTUAL Framework FOR FinANCIAL ACCOUNTING (1983).

75. Copyright (C) Stern Stewarts \& Co.

76. See generally Froud et al, supra note 7. 
uity, including nondistributed-earnings reserve. ${ }^{77}$ The term $k$ is the estimated cost of shareholders' capital. This determination of value added for shareholders implies that the whole "residual income," if positive, should be allocated to shareholding.

In contrast, "Shareholders' Equity Interest" (SEI) and "Shareholders' Equity Share" (SES) may be formalized as follows:

$$
\text { SEI }=i \cdot \text { Cumulated Shareholders' Funds }
$$

$$
S E S=s \cdot \text { Net Earnings }
$$

The term $i$ is the cost of committed shareholders' funds as settled by management, boards of directors, shareholder meetings, statutes, bylaws, financial securities arrangements, securities laws, regulatory bodies, or other institutional arrangements. The term $s$ is the shareholders' share of net enterprise earnings, with a value generally greater than or equal to zero but less than one. In this context, the "cumulated shareholders' funds" implies the separation between funds committed by shareholders, including undistributed past SEIs or SESs, and entity equity, which is mainly composed by cumulated net enterprise earnings after SEIs or SESs. ${ }^{78}$ This definition of shareholders' remuneration implies that only a part of the whole residual income, if positive, may be allocated to shareholders, the remainder being available for prudential and environmental provisions, enterprise continuity, profit-sharing agreements, or donation. This is the accounting way to assure the ongoing capacity of the enterprise entity to generate satisfying performances and fulfil all its obligations over time, including but not limited to shareholders' remuneration. This also constitutes a purpose and scope that can be and has been instituted as an alternative to shareholder value maximization.

More generally, the EVA metric points to the fair value accounting perspective that translates shareholder value rhetoric in accounting regu-

77. Financial analysis sometimes estimates shareholder equity at its market value, which is inconsistent with the enterprise entity approach.

78. Both definitions, as well as EVA, imply the determination of the firm's capital and income. In turn, this determination depends not only on matters of accounting elements' (equity, liability, revenue, and expense) measurement, but also on entity perimeter, and on the recognition of accounting elements. Whether a transaction or a business unit is included in the entity or the distinctions between equity and liability, revenue and liability, and expense and asset, has a distinctive impact on capital and income, and thus on those measures of performance that deal with representation and allocation of resources within the firm. Cf. Yuri Biondi, Cost of Capital, Discounting, and Relational Contracting: Endogenous Optimal Return and Duration of Joint Investment Projects, 43 APPLIED ECON. 4847 (2011); Biondi, Money Without Value, supra note 5; Biondi, The Problem of Social Income, supra note 24; Biondi, The Pure Logic of Accounting, supra note 24. 
lation, while the SEI or SES improves on classic accounting systems based on historical cost invested and revenue generated by the enterprise entity over time. Further, shareholder value replaces the maintenance of past nominal financial commitments with a new concept that includes the opportunity cost of capital, defining shareholder equity in terms of capacity to earn the current market rate of return. ${ }^{79}$ But the enterprise entity approach relies on the specific economic and monetary process of the firm to deliver a financial performance that does not have a market basis. "Historical cost" accounting fits and represents this enterprise process.

Incidentally, control of financial performance does not resolve every matter for which the management of the business firm is accountable. ${ }^{80}$ Regarding this extra-financial dimension of the firm, shareholder value is at odds with the justification of supplementary accounting systems for environmental and societal issues because, under this approach, the social responsibility of business is anything but creating shareholder profits as usual (echoing Friedman's adage). Conversely, the enterprise entity approach may easily provide a more integrated, comprehensive view on accountability of business affairs. Examples of voluntary disclosure regarding this extra-financial dimension already exist, and some jurisdictions have already made it compulsory. ${ }^{81}$

\section{CONCLUSION}

An institutional economic upgrade is required to better understand the firm as an institution and organization with a distinctive role in economy and society. This Article has argued for a comprehensive approach linking economics, accounting, and law around the common notion of the firm as an enterprise entity. ${ }^{82}$ This theoretical development is original, but not isolated in the current debate. Baker, Gibbons, and Murphy speak about the management of off-contractual relations to understand the socioeconomic core of the firm, while Rajan and Zingales are concerned with the integrity of this core against the "dark side of the ownership." 83 Blair and Stout argue for the autonomy and continuity of the

79. The International Accounting Standards Committee (nowadays International Accounting Standards Board) suggested this conception for financial assets and liabilities. INT'L ACCOUNTING StANDARDS COMM., ACCOUNTING FOR FinANCIAL AsSETS AND FinANCIAL LiABILITIES $\S \S 2.4-2.7$ (1997).

80. F.M. SCHERER \& DAvid Ross, Industrial Market Structure AND ECONOMIC PERfoRmANCE (3d ed. 1990); Biondi, The Problem of Social Income, supra note 24; Blair, supra note 7; Robé, supra note 27.

81. Biondi \& Reberioux, supra note 53

82. THE FIRM AS AN ENTITY, supra note 11.

83. See generally George Baker, Robert Gibbons \& Kevin J. Murphy, Bringing the Market Inside the Firm?, 91 AM. ECON. Rev 212 (2001); Raghuram G. Rajan \& Luigi Zingales, Power in a Theory of the Firm, 113 Q.J. ECON. 387 (1998). 
legal-economic entity that concerns various stakeholders, including shareholders, complementing this claim with a constructive critique of the efficient financial market hypothesis. ${ }^{84}$ The enterprise entity view understands the firm as a whole: a dynamic system of relationships, not merely comprising contracts or bargaining. From this perspective, order and disorder, efficiency and waste, honesty and guile, and development and distress have much to do with the structure of these relationships (more so than what existing theories have already recognized). This comprehensive view provides valuable insight into better understanding (1) the fundamental economic nature and very existence of the firm, (2) the separation between ownership, control, and management, and (3) the related systems of governance and disclosure required to control the management of the firm as an enterprise entity.

84. See generally Lynn A. Stout, The Mechanisms of Market Inefficiency, 28 J. CORP. L. 635 (2003); Lynn A. Stout, Inefficient Markets and the New Finance, 14 J. Fin. TRANSFORMATIONS 95 (2005); see also Lynn A. Stout, Risk, Speculation, and OTC Derivatives: An Inaugural Essay for Convivium, 1 ACCT. ECON. \& L. (2011), commented on by Yuri Biondi, Disagreement-Based Trading and Speculation: Implications for Financial Regulation and Economic Theory, 1 ACCT. ECON. \& L. (2011), and by Pierre-Charles M. Pradier, Administering Systemic Risk vs. Administering Justice: What Can We Do Now that We Have Agreed to Pay Differences?, 1 Acct. ECON. \& L. (2011). 